\title{
PULP STONE;
}

A STUDY ON RADIOGRAPHIC ASSESSMENT OF PULP STONE

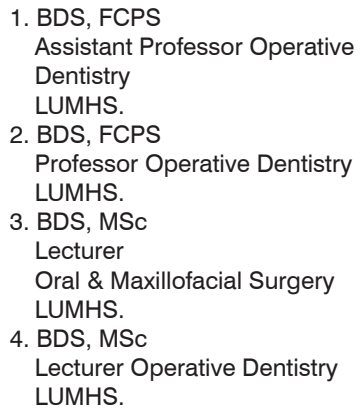

3. BDS, MSc Lecturer Oral \& Maxillofacial Surgery LUMHS.

4. BDS, MSc

Lecturer Operative Dentistry LUMHS.

Correspondence Address: Dr. Salman Shams

B $1 / 2$ Sajjadabad Society Near

Citizen Colony Hyderabad, Sindh.

salman_omfs@hotmail.com

Article received on: 02/12/2016

Accepted for publication: 15/04/2018

Received after proof reading: 00/00/2018

\begin{abstract}
Mahwish Memon', Feroze Ali Kalhoro², Salman Shams ${ }^{3}$, Saba Arain ${ }^{4}$
ABSTRACT... Objectives: To detect the pulp stone radiographically and to investigate any association between the occurrence of pulp stone with age, gender, tooth type, dental arch and tooth status. Study Design: Prospective study. Setting: Department of operative dentistry LUMHS Jamshoro. Period: January 2014 to June 2014. Methodology: A total of 150 patients were randomly selected who came for treatment. All those patients with age range of 11-50 year who had undergone a diagnostic radiographs of premolar and molar region were included in this study. Results: Out of 150 patients pulp stones were detected in 66 patients (44\%). we reported 42 females $(48.27 \%$ ) and 24 males (42.8\%). most of the pulp stones were detected in patients with age $21-30$ years $(52.9 \%)$ followed by $31-40(42.8 \%) .540$ maxillary and 420 mandibular teeth out of 960 total teeth and pulp stones were detected in total 124 teeth 76 maxillary and 48 mandibular. Conclusion: Pulp stone was found more in sound teeth followed by carious teeth and involved mostly molars.
\end{abstract}

Key words: Pulp Stone, Premolar, Molar, Calcification.

Article Citation: Memon M, Kalhoro FA, Shams S, Arain S. Pulp stone; a study on radiographic assessment of pulp stone. Professional Med J 2018; 25(7):992-996. DOI:10.29309/TPMJ/18.3756

\section{INTRODUCTION}

Calcification of dental pulp may be diffuse and discrete in form. Discrete calcification may result in formation of pulp stone. Pulp stone also called as denticles or nodules. Diffuse calcification results in symmetric reduction in the size of pulp chamber and radicular pulp space. ${ }^{1}$ Pulp stones can be found in healthy, diseased and even unerupted teeth. They have calcium phosphorous ratio similar to dentin..$^{2,3}$ They are found more frequently in coronal part of the pulp chamber than radicular canal. Radiographically they appear as radio opaque masses inside radiolucent pulp chamber. ${ }^{2}$

Pulp stones are classified according to structure as 'True' and 'False'. True pulp stones are rare and contain dentin with distinct dentinal tubules lined by odontoblasts. False pulp stones contain concentric layers of mineralized tissue formed by surface accretion around blood thrombi, dying or dead cells, or collagen fibers based on location, pulp stones can be embedded, adherent and free. ${ }^{4}$
Exact cause of pulp stone formation is largely unknown but The implicated factors for pulp stone formation include age, caries, restoration, long standing pulpal irritation, circulatory disturbances in the pulp, orthodontic tooth movement, transplantation of tooth, trauma and systemic problems like cardiovascular diseases ${ }^{5}$. There is also genetic predisposition and sometimes it is considered idiopathic. ${ }^{6,7}$

Prevalence of pulp stones by various studies have been reported to range from $8 \%-90 \% .{ }^{8}$ According to radiographic examination the prevalence is around $20 \%-25 \%{ }^{9}$

The purpose of this study is to detect the pulp stone radiographically and to investigate any association between the occurrence of pulp stone with age, gender, tooth type, dental arch and tooth status.

\section{MATERIAL AND METHODS}

This prospective study was carried out at department of operative dentistry LUMHS 
Jamshoro from January 2014 to June 2014. A total of 150 patients were randomly selected who came for treatment. All those patients with age range of 11-50 year who had undergone a diagnostic radiographs pf premolar and molar region were included in this study.

The radiographs were not taken for the purpose of study. radiographs examined were periapicals and bitewings and viewed under $\mathrm{x}$ ray viewer in a dimmed room. among those 150 patients a total of 960 teeth were examined. Patients demographics age, gender were recorded in a proforma. The tooth was scored as having a pulp stone when a radiopaque mass was present inside the radiolucent pulp chamber. The status of each tooth was categorized as (i) sound (ii) carious (iii) restored. Tooth type, site and dental arch was also recorded on proforma.

The data was analyzed on SPSS version 17 using Pearson chi square test.

\section{RESULTS}

Out of 150 patients pulp stones were detected in 66 patients (44\%) as shown in Figure-1.

\section{Total patient screened $n=150$}

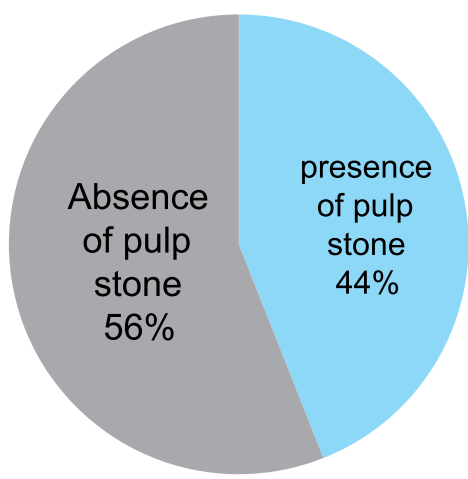

Figure-1.

Out of 66 patients, we reported 42 females (48.27\%) and 24 males (42.8\%) as shown in Figure-2.

\section{Gender distribution among patients with \\ Pulp stones $(n=66)$}

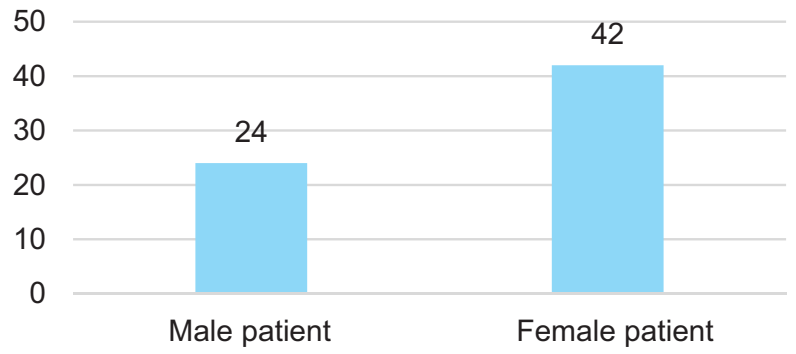

Figure-2.

In this study most of the pulp stones were detected in patients with age $21-30$ years (52.9\%) followed by $31-40(42.8 \%)$. Age distribution of patients in which pulp stone were positive is shown in Table-l.

\begin{tabular}{|c|c|c|c|}
\hline $\begin{array}{c}\text { Patient } \\
\text { age } \\
\text { (y) }\end{array}$ & $\begin{array}{c}\text { No. of } \\
\text { patients } \\
\text { examined }\end{array}$ & $\begin{array}{c}\text { No. of } \\
\text { patients with } \\
\text { pulp stones }\end{array}$ & $\begin{array}{c}\text { \% of patients } \\
\text { with pulp } \\
\text { stones }\end{array}$ \\
\hline $11-20$ & 12 & 04 & $33 \%$ \\
\hline $21-30$ & 68 & 36 & $52.94 \%$ \\
\hline $31-40$ & 42 & 18 & $42.85 \%$ \\
\hline $41-50$ & 28 & 08 & $28.57 \%$ \\
\hline \multicolumn{2}{|c|}{ Table-l. The distribution of pulp stones by Age. } \\
\hline
\end{tabular}

We examined 540 maxillary and 420 mandibular teeth out of 960 total teeth and pulp stones were detected in total 124 teeth 76 maxillary and 48 mandibular.

We detected more pulp stone in maxillary arch $(14.07 \%)$ than the mandibular arch (11.42\%). $1^{\text {st }}$ molar was the mostly commonly involved tooth with pulp stone in both archs. Distribution and percentages of pulp stone among dental arch and tooth type is shown in Table-II and III.

\begin{tabular}{|l|c|c|c|}
\hline & $\begin{array}{c}\text { No. of } \\
\text { Teeth } \\
\text { Examined }\end{array}$ & $\begin{array}{c}\text { No. of Teeth } \\
\text { with Pulp } \\
\text { Stones }\end{array}$ & $\%$ \\
\hline Maxillary arch & 540 & 76 & $14.07 \%$ \\
\hline Mandibular arch & 420 & 48 & $11.42 \%$ \\
\hline Total & 960 & 124 & $12.91 \%$ \\
\hline Table-II. Distribution of pulp stones by dental arch.
\end{tabular}




\begin{tabular}{|l|c|c|c|}
\hline Maxillary Arch & $\begin{array}{c}\text { No. of } \\
\text { Teeth } \\
\text { Examined }\end{array}$ & $\begin{array}{c}\text { Teeth } \\
\text { with Pulp } \\
\text { Stone }\end{array}$ & $\begin{array}{c}\text { \% of Teeth } \\
\text { with Pulp } \\
\text { Stones }\end{array}$ \\
\hline $1^{\text {st }} \mathrm{PM}$ & 55 & 01 & $1.8 \%$ \\
\hline $2^{\text {nd }} \mathrm{PM}$ & 85 & 03 & $3.5 \%$ \\
\hline $1^{\text {st }} \mathrm{M}$ & 200 & 43 & $21.5 \%$ \\
\hline $2^{\text {nd }} \mathrm{M}$ & 200 & 30 & $15 \% *$ \\
\hline Mandibular arch & & & \\
\hline $1^{\text {st }} \mathrm{PM}$ & 55 & 01 & $1.8 \%$ \\
\hline $2^{\text {nd }} \mathrm{PM}$ & 65 & 02 & $3.07 \%$ \\
\hline $1^{\text {st }} \mathrm{M}$ & 145 & 29 & $20 \% *$ \\
\hline $2^{\text {nd }} \mathrm{M}$ & 140 & 16 & $11.42 \%$ \\
\hline
\end{tabular}

Table-III. Distribution of pulp stone by Tooth type.

\begin{tabular}{|l|c|c|}
\hline Tooth Status & $\begin{array}{c}\text { No. of Teeth with } \\
\text { Pulp Stone }\end{array}$ & $\%$ \\
\hline Sound & 59 & $47 \%$ \\
\hline Carious & 47 & $37.9 \%$ \\
\hline Restored & 18 & $14.5 \%$ \\
\hline \multicolumn{2}{|c|}{ Table-IV. Association of pulp stone with tooth status. } \\
\hline
\end{tabular}

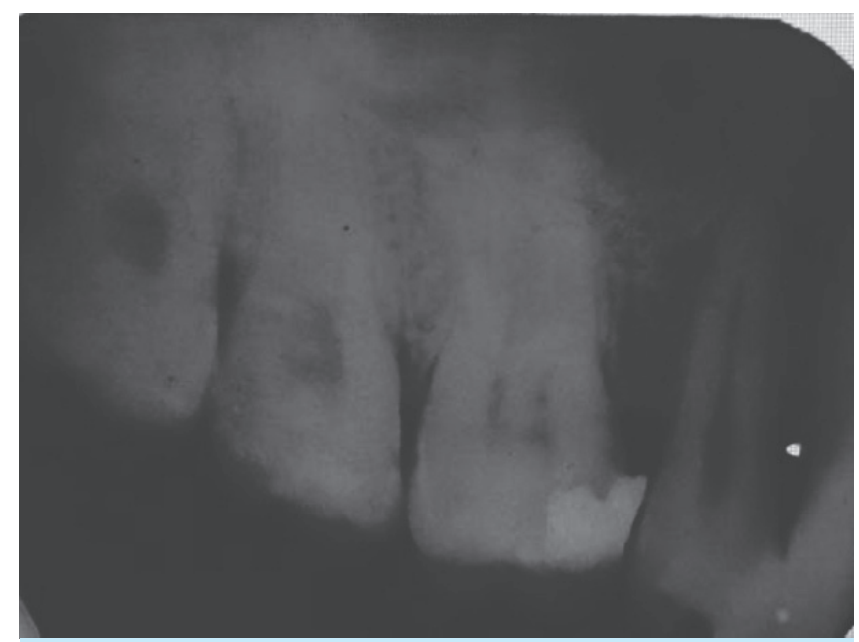

Figure-3. Pulp stone associated with maxillary $1^{\text {st }}$ molar

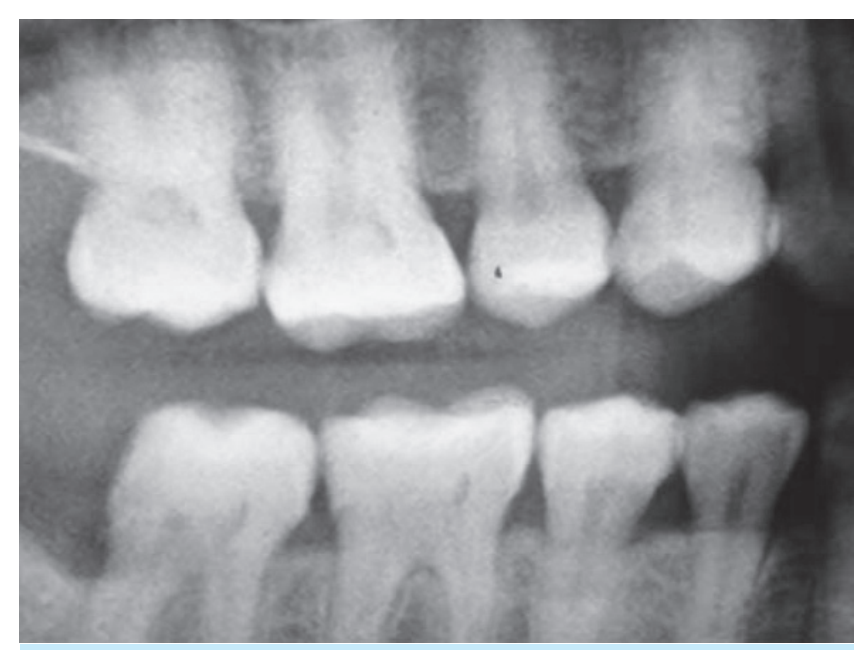

Figure-4. Pulp stone associated with intact molars

\section{DISCUSSION}

Pulp stones can only be detected on radiographs when they are larger than $200 \mu \mathrm{m}$ in diameter. ${ }^{8}$ Radiographs are the non-invasive technique of detecting the pulp stone in a clinical setting. ${ }^{5}$ True prevalence is higher in microscopic examination of teeth than figures from radiographic studies. ${ }^{8}$ In this study we used periapical and bitewing radiographs to detect presence of pulp stones. kannan et al ${ }^{10}$ stated that bitewing do not show the complete radicular pulp, so they examined only periapical x-rays. However Tames et al ${ }^{11}$ stated no significant difference in the identification of pulp stones by bitewing and periapical radiographs.

According to renjitker et al the reported prevalence of pulp stones in 217 Australian dental students were found to be $46 \%$ of the subjects and $10 \%$ of the teeth. ${ }^{5}$ Another study on prevalence of pulpstones reported incidence to be $4.8 \%$ in 747 out of 15,326 teeth examined. ${ }^{12}$ Kannan et al ${ }^{10}$ examined 361 Malaysian and reported 44.9 of the subjects with pulp stones and $15.7 \%$ of the teeth examined.

In our study prevalence was higher in females compared with males. This is in accordance with previous studies which reported higher prevalence in women. ${ }^{10,13}$

In the present study the maximum numbers of pulp stones were detected in 21-30 years of age group followed by 31-40 years. This may be because most of the patients examined were in this age group. However, previous studies reported older adults i.e more than 60 years had significantly higher prevalence of pulp stones. In our study, more pulp stones were detected in maxillary arch than mandibular. This was in agreement with the Rangitker S. ${ }^{5}$ Similar frequencies in both maxillary and mandibular $\operatorname{arch}^{10}$, and higher prevalence in mandibular arch have also been reported. ${ }^{14}$ Occurrence of pulp stones was higher in first molar than second molar. This was also in agreement with most studies. 5,10,13 This finding may be related to the fact that the molars are the largest teeth in the arch, have a better supply of blood to the pulp tissue and have strong chewing force in the arch. This may lead to greater 
precipitation for calcification.

In the present study significant association between presence of pulp stone and carious teeth was found. This may be because of pulpal irritation in carious teeth that may trigger a defense reaction in dentin pulp complex causing pulpal calcification. Occurrence of pulp stone was higher in sound and carious teeth than restored teeth (Figure-1 and 2) this was consistent with the finding of ranjitkar $\mathrm{S}$. The presence of pulp stone in very young teeth and developing tooth germ, indicates that the pulpal pathology is unlikely to be only aetiological factor for pulp stone formation. One of the recent research isolated calcifying nanoparticles in the etiology of pulp stone formation long term use of medications also a contribution factor for pulp chamber calcification because of increase odontoblast activity. ${ }^{17,18}$

From the clinical perspective, the current view is that the pulp stones have no clinical significance other than causing difficulties during endodontic treatment leading to hindering canal location and negotiation. Investigators reported the correlation of pulp stone with cardiovascular disease and other systemic diseases. ${ }^{15}$ One study reported higher prevalence of pulp stone in patients with hypertension, diabetes and gastritis. ${ }^{16}$ This indicates that of pulp stone is found incidentally in the pulp tissue of asymptomatic vital pulps, may play an important role in the diagnosis of a serious underlying disease or condition. So further studies on association of pulp stones with systemic diseases should be recommended.

\section{CONCLUSION}

The prevalence of pulp stones in the studied population of LUMHS was $44 \%$ of subjects and $12.9 \%$ of teeth examined. Pulp stone was found more in sound teeth followed by carious teeth and involved mostly molars.

The size, shape, location, and number of pulp stones on radiographs can be used as adjunctive feature for forensic identification.

Copyright@ 15 Apr, 2018.
REFERENCES

1. Sener S, Cobankara FK, Akgunlu F. Calcifications of the pulp chamber: prevalence and implicated factors. Clin Oral Investig 2009; 13:209-15.

2. Nanci Antonio. Ten Cate's Oral Histology: Development, structure, and function, $8^{\text {th }}$ ed. St Louis: Mosby; 2013:201-2.

3. Langeland K, Rodrigues H, Doeden W. Periodontal disease bacteria, and pulpal histopathology. Oral Surg Oral Med Oral Pathol 1974; 37:257-70.

4. Seltzer S, bender IB. the dental pulp, $3^{\text {rd }}$ edn. Philadelphia, PA: J.B. Lippincott Company.

5. Ranjitkar S, Taylor JA, Townsend GC. A radiographic assessment of prevalence pulp stones in Australians. Aust Dent J 2002; 47:36-40.

6. Bauss O, Neter D, Rahman A. Prevalence of pulp calcifications in patients with Marfan syndrome. Oral Surg Oral Med Oral Pathol Oral Rdiol Endod 2008; 106:e56-61.

7. Parekh S, Kyriazidou A, Bloch-Zupan A, Roberts G. Multiple pulp stones and short- ened roots of unknown etiology. Oral Surg Oral Med Oral Pathol Oral Radiol Endod 2006; 101:e139-42.

8. Moss-Salentijin L, Hendricks-Klyvert MS. Calcified structures in the human dental pulps. J Endod 1988; 14:184-9.

9. Hamasha AA, Darwazeh A. Prevalence of pulp stones in Jordanian adults. Oral Surg Oral Med Oral Pathol Oral Radiol Endod 1998; 86:730-2.

10. Kannan S, kannepady SK, muthu K. Radiographic assessment of the prevalence of pulp stones in Malaysians. J Endod 2015; 41:333-7.

11. Tamse A, Kaffe I, Littner MM, Shani R. Statistical evaluation of radiologic survey of pulp stones. $J$ Endod 1982; 8:455-8.

12. Sener S, Cobankara FK, Akgunlu F,

13. Sisman $Y$, Aktan AM, Ertas TE. The prevalence of pulp stones in a Turkish population. A radiographic survey. Med Oral Patol Oral Cir Bucal. 2012; 17:e212-7.

14. Elvery MW, Savage NW, Wood WB. Radiographic study of broad breach aboriginal dentition. Am J Phys Anthropol 1998; 107:211-19.

15. Edds AC, Walden JE, Scheetz JP, Goldsmith LJ, Drisko $\mathrm{CL}$, Eleazer PD. Pilot study of correlation of pulp stones with cardiovascular disease. J Endod 2005; 


\section{1:504-6.}

16. Talla HV, Kommineni NK, Yalamancheli S. A study on pulp stones in a group of the population in Andhra Pradesh, India: An institutional study. J Conser Dent 2014; 17:111-114.
17. Zeng J, Yang F, Zhang W, et al. Association between dental pulp stones and calcifying nanoparticles. Int $\mathrm{J}$ Nanomedicine 2011; 6:109-18.

18. Pettiet MT, Zhong S, Moretti AJ. Potential correlation between statins and pulp chamber calcification. J Endod 2013; 9:1119-23.

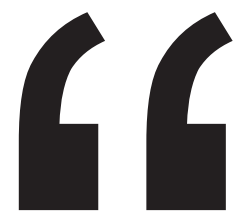

Knowing The Truth, Seeing The Truth, but still Believing The Lies.

\section{AUTHORSHIP AND CONTRIBUTION DECLARATION}

\begin{tabular}{|c|l|l|l|}
\hline Sr. \# & \multicolumn{1}{|c|}{ Author-s Full Name } & \multicolumn{1}{|c|}{ Contribution to the paper } & Author=s Signature \\
\hline 1 & Mahwish Memon & Study conception and design. \\
\hline 2 & Feroze Ali Kalhoro & Acquisition of data. \\
\hline 4 & Salman Shams & $\begin{array}{l}\text { Plagiarism check Analysis and } \\
\text { interpretation of data. } \\
\text { Acquisition of data \& Drafting } \\
\text { of manuscript. }\end{array}$ \\
\hline
\end{tabular}

